\title{
PENGARUH KETERLIBATAN KERJA, LINGKUNGAN KERJA DAN BUDAYA KERJA TERHADAP KINERJA KARYAWAN PADA PT TOLAN TIGA INDONESIA PERLABIAN LABUHANBATU SELATAN
}

\author{
Prista Maya Dewi ${ }^{1}$, Pristiyono ${ }^{2}$ \\ ${ }^{1}$ Alumni Sarjana Ekonomi STIE Labuhanbatu \\ ${ }^{2}$ Dosen STIE Labuhanbatu
}

\begin{abstract}
ABSTRAK
Kinerja karyawan mengacu pada prestasi seseorang yang diukur berdasarkan standar atau kriteria yang ditetapkan oleh perusahaan. Pengelolaan untuk mencapai kinerja sumber daya manusia tinggi dimaksudkan guna meningkatkan perusahaan secara keseluruhan. Penelitian ini bertujuan untuk mengetahui pengaruh keterlibatan kerja secara parsial terhadap $\mathrm{k}$ kinerja karyawan PT Tolan Tiga Indonesia Perlabian Labuhanbatu Selatan. Untuk mengetahui pengaruh lingkungan kerja secara parsial terhadap kinerja karyawan PT Tolan Tiga Indonesia Perlabian Labuhanbatu Selatan. Untuk mengetahui pengaruh budaya kerja secara parsial terhadap kinerja karyawan PT Tolan Tiga Indonesia Perlabian Labuhanbatu Selatan. Untuk mengetahui pengaruh keterlibatan kerja, lingkungan kerja dan budaya kerja secara serempak terhadap kinerja karyawan PT Tolan Tiga Indonesia Perlabian Labuhanbatu Selatan. Subjek penelitian ini dilakukan pada PT Tolan Tiga Indonesia Perlabian Labuhanbatu Selatan dengan populasi berjumlah 49 orang sehingga seluruh populasi tersebut merupakan sampel keseluruhan dengan teknik sampling jenuh. Teknik pengumpulan data dilakukan dengan kuesioner atau data sekunder. Teknik analisis data menggunakan analisis regresi linier berganda dengan software SPSS. Hasil penelitian menunjukkan secara serempak variabel keterlibatan kerja, lingkungan kerja dan budaya kerja berpengaruh positif dan signifikan terhadap kinerja karyawan. Secara parsial variabel keterlibatan kerja paling dominan berpengaruh positif dan signifikan terhadap kinerja karyawan. Secara parsial variabel lingkungan kerja tidak berpengaruh positif dan signifikan terhadap kinerja karyawan. Secara parsial budaya kerja berpengaruh positif dan tidak signifikan terhadap kinerja karyawan.

Kata Kunci : Keterlibatan Kerja, Lingkungan Kerja, Budaya Kerja, Kinerja Karyawan.
\end{abstract}

\section{PENDAHULUAN}

\section{Latar Belakang Masalah}

Perusahaan dalam menghadapi globalisasi ekonomi membutuhkan sumber daya manusia (SDM) yang tangguh. Inilah salah satu unsur penentu perusahaan bakal mampu bersaing di pasar global. Untuk itu, perusahaan perlu membangun kepercayaan atau nilai dikalangan karyawannya, yaitu tekad untuk selalu bekerja berbasiskan standar mutu tinggi. Semakin tinggi standar, maka akan semakin berpeluang perusahaan untuk makin maju. Selain unsur kepercayaan, perusahaan juga hendaknya mampu membangun sikap pentingnya meraih kinerja unggul.

Kinerja karyawan mengacu pada prestasi seseorang yang diukur berdasarkan standar atau kriteria yang 
ditetapkan oleh perusahaan. Pengelolaan untuk mencapai kinerja sumber daya manusia tinggi dimaksudkan guna meningkatkan perusahaan secara keseluruhan. Kinerja sebenarnya merupakan konsep yang sangat kompleks, baik definisi maupun pengukurannya yang sering menjadi tantangan bagi peneliti teori manajemen dan perilaku organisasi, karena bersifat multidimensional, sehingga pengukuran kinerja hendaknya menginteraksikan dimensi pengukuran yang beragam.

Kinerja karyawan adalah tingkat pencapaian hasil atas pelaksanaan tugas tertentu seorang karyawan. Manajemen kinerja adalah keseluruhan kegiatan yang dilakukan untuk meningkatkan kinerja perusahaan atau organisasi, termasuk kinerja masing-masing individu dan kelompok kerja di perusahaan tersebut.

Kinerja karyawan dapat dipengaruhi oleh keterlibatan kerja. Keterlibatan kerja yang dilakukan karyawan timbul sebagai respon terhadap suatu pekerjaan atau situasi tertentu dalam lingkungan kerja. Dengan kata lain suatu jenis pekerjaan atau situasi dalam lingkungan kerja akan mempengaruhi orang tersebut makin terlibat atau tidak dalam pekerjaannya. Dalam hal ini yaitu keterkaitan seseorang dalam pekerjaan diluar dari pekerjaan yang sebenarnya ditanggung.

Kinerja karyawan dapat terlaksana apabila didukung dengan lingkungan kerja yang efektif dan efisien. Lingkungan kerja merupakan salah satu variabel independen yang sangat menentukan kesuksesan tujuan perusahaan. Secara umum lingkungan kerja yang baik dan sehat bagi karyawan dapat meningkatkan kualitas kerja sekaligus kehidupan dalam organisasi melalui kinerja karyawan. Meskipun lingkungan kerja tidak melaksanakan proses produksi dalam suatu perusahaan, namun lingkungan kerja mempunyai pengaruh langsung terhadap kinerja karyawan.

Lingkungan kerja dapat menciptakan hubungan kerja yang mengikat antara orang-orang yang ada didalam lingkungannya. Oleh karena itu, hendaknya diusahakan agar lingkungan kerja harus baik dan kondusif menjadikan karyawan merasa betah berada diruangan dan merasa senang serta bersemangat untuk melaksankan setiap tugas-tugasnya.

Budaya kerja memiliki pengaruh positif terhadap peningkatan kinerja karyawan. Maka dari itu, kesuksesan perusahaan yang memiliki budaya kerja apik dan modern selanjutnya akan berdampak positif pada kinerja karyawan sementara kegagalannya berarti memberi dampak negatif terhadap kinerja karyawan.

\section{Rumusan Masalah}

Berdasarkan uraian latar belakang penelitian, maka dapat dirumuskan permasalahan dalam penelitian ini, yaitu :

a. Apakah keterlibatan kerja secara parsial berpengaruh terhadap kinerja karyawan?

b. Apakah lingkungan kerja secara parsial berpengaruh terhadap kinerja karyawan?

c. Apakah budaya kerja secara parsial berpengaruh terhadap kinerja karyawan?

d. Apakah keterlibatan kerja, lingkungan kerja dan budaya kerja secara serempak berpengaruh terhadap kinerja karyawan?

\section{Tujuan Penelitian}

adalah : 
1. Untuk mengetahui pengaruh keterlibatan kerja secara parsial terhadap kinerja karyawan.

2. Untuk mengetahui pengaruh lingkungan kerja secara parsial terhadap kinerja karyawan.

3. Untuk mengetahui pengaruh budaya kerja secara parsial terhadap kinerja karyawan.

4. Untuk mengetahui pengaruh keterlibatan kerja, lingkungan kerja dan budaya kerja secara serempak terhadap kinerja karyawan.

\section{Manfaat Penelitian}

Manfaat dari penelitian ini antara lain :

1. Bagi Penulis

Sebagai peluang untuk menggali dan mengaplikasikan ilmu yang diperoleh selama studi di Sekolah Tinggi Ilmu Ekonomi Labuhanbatu pada program studi manajemen khususnya bidang manajemen yang berkaiatan dengan sumber daya manusia.

2. Bagi Perusahaan

Sebagai dasar pemikiran PT Tolan Tiga Indonesia Perlabian Labuhanbatu Selatan dalam upaya meningkatkan kinerja melalui pendekatan keterlibatan kerja, lingkungan kerja dan budaya kerja.

3. Bagi Peneliti Lain

Sebagai sumber referensi yang relevan bagi peneliti lain yang ingin meneliti variabel sejenis di masa mendatang.

4. Bagi STIE Labuhanbatu

Sebagai khasanah keilmuan kepustakaan STIE Labuhanbatu dalam penelitian

\section{LANDASAN TEORI}

Penelitian Terdahulu

Berikut ini referensi penelitian terdahulu yang relevan dengan penelitian, sebagai berikut :

1. Logahan dan Aesaria (2014) yang berjudul "Budaya Organisasi Dan Keterlibatan Kerja Terhadap Komitmen Organisasi Berdampak Pada Kinerja Karyawan Pada BTN - Ciputat". Tujuan penelitian ini adalah untuk mengetahui pengaruh budaya organisasi dan keterlibatan kerja terhadap komitmen organisasi dan dampaknya terhadap kinerja karyawan pada PT. Bank Tabungan Negara, Tbk cabang Ciputat. Metode yang digunakan dalam penelitian ini adalah path analysis.

2. Arianto (2013) dalam berjudul "Pengaruh Kedisiplinan, Lingkungan Kerja Dan Budaya Kerja Terhadap Kinerja Tenaga Pengajar". Penelitian ini bertujuan untuk menganalisis pengaruh kedisiplinan kerja, lingkungan kerja dan budaya kerja terhadap kinerja tenaga pengajar. Populasi dalam penelitian ini adalah seluruh tenaga pengajar Yaspenlub Demak. Pengumpulan data menggunakan kuesioner dan dianalisis dengan regresi linear ganda.

\section{Uraian Teoritis \\ Keterlibatan Kerja}

Menurut Perot (dalam Kartiningsih, 2007) menambahkan bahwa keterlibatan kerja adalah derajat sejauh mana individu merasa berpartisipasi secara aktif dalam pekerjaannya atau sampai sejauh mana individu mencari 
ekspresi diri dan aktualisasi diri dalam pekerjaannya. Lodahl dan Kejner (dalam Cilliana dan Mansoer, 2008) menyatakan keterlibatan kerja adalah seberapa besar identifikasi secara psikologis individu terhadap pekerjaannya. Makin besar individu tersebut mengidentifikasikan dirinya dengan pekerjaannya, maka keterlibatan kerja semakin tinggi. Namun, perlu diingat bahwa individu yang terlibat dalam pekerjaannya belum tentu merasa senang dengan pekerjaannya karena pada kenyataannya individu yang merasa tidak senang dengan pekerjaannya juga dapat memiliki derajat keterlibatan yang sama dengan individu yang menyukai pekerjaannya.

Keterlibatan kerja merupakan tingkat di mana seseorang mengaitkan dirinya ke pekerjaannya, secara aktif berpartisipasi di dalamnya dan menganggap kinerjanya penting bagi nilai dirinya. Keterlibatan karyawan adalah proses partisipatif yang menggunakan seluruh kapasitas pekerja dan dirancang untuk mendorong meningkatkan komitmen demi keberhasilan perusahaan.

\section{Lingkungan Kerja}

Lingkungan kerja dalam suatu perusahaan merupakan salah satu hal yang penting untuk diperhatikan. Meskipun lingkungan kerja tidak melaksanakan proses produksi dalam suatu perusahaan, namun lingkungan kerja mempunyai pengaruh langsung terhadap para karyawan yang melaksanakan tugas-tugas dari perusahaan. Menurut Sedarmayanti (2009) jenis lingkungan kerja secara garis besar terbagi menjadi 2 yaitu: lingkungan kerja fisik dan lingkungan kerja non fisik.

\section{Faktor-faktor yang Mempengaruhi Lingkungan Kerja}

Menurut Sedarmayanti (2009) faktor-faktor yang dapat mempengaruhi lingkungan kerja antara lain:

a. Penerangan

Cahaya atau penerangan sangat besar manfaatnya bagi para karyawan guna menbdapat keselamatan dan kelancaran kerja. Pada dasarnya, cahaya dapat dibedakan menjadi dua bagian, yaitu: cahaya yang berasal dari sinar matahari dan cahaya buatan berupa lampu. Oleh sebab itu perlu diperhatikan adanya penerangan (cahaya) yang terang tetpai tidak menyilaukan.

b. Hubungan Karyawan

Lingkungan kerja yang menyenangkan bagi karyawan melalui pengikatan hubungan yang harmonis dengan atasan, rekan kerja, maupun bawahan serta didukung oleh sarana dan prasarana yang memadai yang ada di tempat bekerja akan membawa dampak yang positif bagi keryawan, sehingga kinerja karyawan dapat meningkat.

\section{Budaya Kerja}

Budaya kerja adalah suatu falsafah dengan didasari pandangan hidup sebagai nilai-nilai yang menjadi sifat, kebiasaan dan juga pendorong yang dibudayakan dalam suatu kelompok dan tercermin dalam sikap menjadi perilaku, cita-cita, pendapat, pandangan serta tindakan yang terwujud sebagai kerja. (http://faridaniva.blogspot.co.id/2013/12/ makalah-budaya-kerja.html).

Budaya kerja memiliki tujuan untuk mengubah sikap dan juga perilaku SDM yang ada agar dapat meningkatkan produktivitas kerja untuk menghadapi berbagai tantangan di masa yang akan 
datang.Manfaat dari penerapan Budaya Kerja yang baik :

\section{Kinerja Karyawan}

Pada dasarnya seorang karyawan dalam melaksanakan dan menyelesaikan tugas yang dibebankan kepadanya diharapkan untuk dapat menunjukkan suatu inerja terbaik yang bisa ditunjukkan oleh karyawan tersebut. Selain itu kinerja seorang karyawan dipengaruhi oleh berbagai faktor yang penting guna untuk meningkatkan hasil kerjanya.

\section{Hipotesis Penelitian}

Berdasarkan kerangka pemikiran yang telah diuraikan, maka dapat hipotesis dalam penelitian ini adalah :

1. Keterlibatan kerja secara parsial berpengaruh terhadap kinerja karyawan.

2. Lingkungan kerja secara parsial berpengaruh terhadap kinerja karyawan.

3. Budaya kerja secara parsial berpengaruh terhadap kinerja karyawan

4. Keterlibatan kerja, lingkungan kerja dan budaya kerja berpengaruh secara serempak terhadap kinerja karyawan.

\section{METODE PENELITIAN}

\section{Populasi}

Menurut Ferdinand (2006), populasi adalah gabungan dari seluruh elemen yang berbentuk peristiwa, hal atau orang yang memiliki karakteristik yang serupa yang menjadi pusat perhatian seorang peneliti, karena itu dipandang sebagai sebuah semesta penelitian. Populasi dalam penelitian ini merupakan seluruh staf karyawan PT Tolan Tiga
Perlabian Kabupaten Labuhanbatu Selatan berjumlah 49 karyawan.

Sampel

Menurut Ferdinand (2006), sampel merupakan subset dari populasi, terdiri dari beberapa anggota populasi. Metode pengambilan sampel menggunakan tehnik Sampling Jenuh yaitu teknik penentuan sampel bila semua anggota populasi digunakan sebagai sampel. Hal ini sering dilakukan bila jumlah populasi relatif kecil. Sampel yang digunakan dalam penelitian ini adalah seluruh staf karyawan PT Tolan Tiga Indonesia Perlabian Labuhanbatu Selatan berjumlah 49 karyawan.

Definisi Operasional Variabel

Dalam penelitian ini terdapat empat variabel yang diteliti yang terdiri dari :

1. Variabel independ ariabel bebas)

2. Variabel dependen (variabel terikat)

\section{Metode Analisis Data}

Teknik analisis data yang digunakan pada penelitian ini yaitu :

\section{Deskriptif Statistik}

Analisis deskriptif, merupakan suatu cara menganalisis dimana data yang sudah dikumpulkan, dikelompokkan, dianalisis dan diinterpretasikan sehingga diperoleh gambaran yang jelas tentang objek yang diteliti.

\section{Analisis Regresi Linier Berganda}

Analisis regresi liniear berganda digunakan untuk mengetahui pengaruh variabel bebas (X) yang lebih dari 2 (dua) variabel terhadap variabel terikat (Y). Pengolahan data dilakukan dengan menggunakan bantuan software SPSS 20.00 for windows. Analisis regresi berganda menggunakan persamaan, sebagai berikut: 


$$
\mathbf{Y}=\mathbf{a}+\mathbf{b}_{1} \mathbf{X}_{1}+\mathbf{b}_{2} \mathbf{X}_{2}+\mathbf{b}_{3} \mathbf{X}_{3}+\mathbf{e}
$$

\section{Uji Hipotesis}

Setelah persamaan regresi didapat, maka tahap berikutnya adalah melakukan pengujian terhadap hipotesis penelitian untuk mengetahui apakah variabel keterlibatan kerja $\left(\mathrm{X}_{1}\right)$, lingkungan kerja $\left(\mathrm{X}_{2}\right)$, dan budaya kerja $\left(\mathrm{X}_{3}\right)$ dapat digunakan untuk memprediksi variabel kinerja karyawan $(\mathrm{Y})$.

Pengujian hipotesis tersebut dilakukan dengan uji statistik yaitu :

a. Uji Simultan (Uji F)

Uji statistik $F$ pada dasarnya menunjukkan apakah semua variabel independen keterlibatan kerja $\left(\mathrm{X}_{1}\right)$, lingkungan kerja $\left(\mathrm{X}_{2}\right)$, dan budaya kerja $\left(\mathrm{X}_{3}\right)$ mempunyai pengaruh secara serempak terhadap variabel dependen kinerja karyawan (Y).

Kriteria pengujian : Jika tingkat signifikansi $\mathrm{F}>0,05$ atau $\mathrm{F}$ hitung $<\mathrm{F}$ tabel, maka Ho diterima.

Jika tingkat signifikansi $\mathrm{F}<0,05$ atau $\mathrm{F}$ hitung $>\mathrm{F}$ tabel, maka Ho ditolak.

b. Uji Parsial (Uji t)

Uji statistik pada dasarnya menunjukkan seberapa jauh pengaruh satu variabel penjelas/ keterlibatan kerja $\left(\mathrm{X}_{1}\right)$, lingkungan kerja $\left(\mathrm{X}_{2}\right)$, dan budaya kerja $\left(\mathrm{X}_{3}\right)$ mempunyai pengaruh secara parsial terhadap variabel dependen kinerja karyawan (Y). berikut: Kriteria pengujiannya sebagai

Jika probabilitas (signifikansi) lebih besar dari $0,05(\alpha)$, maka variabel independen secara individual tidak berpengaruh terhadap variabel dependen.
Jika probabilitas (signifikansi) lebih kecil dari 0,05 ( $\alpha$ ), maka variabel independen secara individual berpengaruh terhadap variabel dependen.

\section{Pengujian Asumsi Klasik}

Uji asumsi klasik dilakukan sebelum melakukan analisis regresi, agar didapat perkiraan yang tidak biasa dan efisiensi maka dilakukan pengujian asumsi klasik yang harus dipenuhi, yaitu:

\section{a. Uji Normalitas}

Uji normalitas adalah untuk mengetahui distribusi sebuah data mengikuti atau mendekati distribusi normal. Uji normalitas dilakukan dengan menggunakan pendekatan kolmogrov smimov. Dengan menggunakan tingkat signifikan 5\% maka nilai Asymp.sig. (2-tailed) diatas nilai signifikan $5 \%$ artinya variabel residual berdistribusi normal.

\section{b. Uji Multikolineritas}

Artinya variabel independen yang satu dengan yang lain dalam model regresi berganda tidak saling berhubungan secara sempurna. Untuk mengetahui ada tidaknya gejala multikolinearitas dapat dilihat dari besarnya Tolerance dan VIF (Variance Inflation Factor) melalui program SPSS. Tolerance mengukur variabilitas variabel terpilih yang tidak dijelaskan oleh variabel independen lainnya. Nilai umum yang biasa dipakai adalah nilai Tolerance $>$ 1 atau nilai $\mathrm{VIF}<5$, maka tidak terjadi multikolinearitas.

\section{c. Uji Heteroskedastisitas}

Uji Heteroskedastisitas varians variabel independen adalah konstanta untuk setiap nilai tertentu variabel independen (homokedastisitas). Model regresi yang baik adalah tidak terjalin heteroskedastisitas. Heteroskedastisitas diuji dengan 
menggunakan uji Gletser dengan pengambilan keputusan jika variabel independen signifikan secara statistik mempengaruhi variabel independen, maka ada indikasi terjadinya heteroskedastisitas. Jika probabilitas signifikannya diatas tingkat kepercayaan 5\% dapat disimpulkan model regresi tidak mengarah adanya heteroskedastisitas.

\section{HASIL DAN PEMBAHASAN}

\section{Hasil Penelitian}

\section{Hasil Deskriptif Responden Penelitian}

Hasil deskriptif responden ini dilakukan untuk mengetahui dan mengklasifikasi profil responden sesuai dengan informasi kuesioner penelitian. Adapun deskriptif responden antara lain :

Deskriptif responden berdasarkan usia pada responden Perlabian Labuhanbatu Selatan sebagai berikut :

Tabel 1

Deskripsi Usia Responden

\begin{tabular}{|c|c|c|c|}
\hline No. & Usia & $\begin{array}{c}\text { Jumlah } \\
\text { (Orang) }\end{array}$ & $\begin{array}{c}\text { Persentase } \\
(\%)\end{array}$ \\
\hline 1. & $21-26$ tahun & 11 & $22,5 \%$ \\
\hline 2. & $27-32$ tahun & 9 & $18,4 \%$ \\
\hline 3. & $33-38$ tahun & 13 & $26,5 \%$ \\
\hline 4. & $39-44$ tahun & 10 & $20,5 \%$ \\
\hline 5. & $\geq 45$ tahun & 6 & $12,5 \%$ \\
\hline & Jumlah & 49 & $\mathbf{1 0 0}$ \\
\hline
\end{tabular}

Deskriptif responden berdasarkan jenis kelamin responden Perlabian Labuhanbatu Selatan sebagai berikut :

Tabel 2

Deskripsi Jenis Kelamin Responden

\begin{tabular}{|c|c|c|c|}
\hline No. & Jenis Kelamin & $\begin{array}{c}\text { Jumlah } \\
\text { (Orang) }\end{array}$ & $\begin{array}{c}\text { Persentase } \\
(\%)\end{array}$ \\
\hline 1. & Perempuan & 5 & $10,2 \%$ \\
\hline 2. & Laki-laki & 44 & $89,8 \%$ \\
\hline \multicolumn{2}{|c|}{ Jumlah } & $\mathbf{4 9}$ & $\mathbf{1 0 0}$ \\
\hline
\end{tabular}

Sumber : Hasil Penelitian (2016)
Deskriptif responden berdasarkan pendidikan terakhir responden Perlabian Labuhanbatu Selatan sebagai berikut :

Tabel 3

Deskripsi Pendidikan Terakhir Responden

\begin{tabular}{|c|c|c|c|}
\hline No. & Pendidikan Terakhir & $\begin{array}{c}\text { Jumlah } \\
\text { (Orang) }\end{array}$ & $\begin{array}{c}\text { Persentase } \\
(\mathbf{\%})\end{array}$ \\
\hline 1. & SMU Sederajat & 24 & $48,9 \%$ \\
\hline 2. & Diploma & 9 & $18,3 \%$ \\
\hline 3. & Sarjana & 16 & $36,6 \%$ \\
\hline \multicolumn{2}{|c|}{ Jumlah } & $\mathbf{4 9}$ & $\mathbf{1 0 0}$ \\
\hline
\end{tabular}

Sumber : Hasil Penelitian (2016)

Deskriptif responden berdasarkan masa kerja responden Perlabian Labuhanbatu Selatan sebagai berikut :

Tabel 4

Deskripsi Masa Kerja Responden

\begin{tabular}{|c|c|c|c|}
\hline No. & Masa Kerja & $\begin{array}{c}\text { Jumlah } \\
\text { (Orang) }\end{array}$ & $\begin{array}{c}\text { Persentase } \\
\text { (\%) }\end{array}$ \\
\hline 1. & $1-10$ tahun & 37 & $75,5 \%$ \\
\hline 2. & $11-20$ tahun & 12 & $24,5 \%$ \\
\hline \multicolumn{2}{|c|}{ Jumlah } & $\mathbf{4 9}$ & $\mathbf{1 0 0}$ \\
\hline
\end{tabular}

\section{Hasil Pengujian Asumsi Klasik}

Pengujian Asumsi Normalitas

Untuk mengetahui bahwa model regresi memenuhi asumsi normalitas dengan menggunakan pendekatan secara statistik dengan bantuan software SPSS pada pengujian 1- Sample Kolmogrov Smirnov, dapat dilihat pada Tabel 5 berikut : 
Tabel 5

One-Sample Kolmogorov-Smirnov Test

\begin{tabular}{|c|c|c|}
\hline & & $\begin{array}{c}\text { Unstandardized } \\
\text { Residual }\end{array}$ \\
\hline \multicolumn{2}{|l|}{$\mathrm{N}$} & 49 \\
\hline \multirow[t]{2}{*}{ Normal Parameters ${ }^{\mathrm{a}, \mathrm{b}}$} & Mean & .0000000 \\
\hline & Std. Deviation & 1.84730148 \\
\hline \multirow[t]{3}{*}{ Most Extreme Differences } & Absolute & .079 \\
\hline & Positive & .059 \\
\hline & Negative & -.079 \\
\hline \multicolumn{2}{|l|}{ Kolmogorov-Smirnov Z } & .550 \\
\hline \multicolumn{2}{|l|}{ Asymp. Sig. (2-tailed) } & .923 \\
\hline
\end{tabular}

Pengujian Multikolinearitas

Hasil pengujian asumsi multikolinearitas sebagai berikut :

Tabel 6

Uji Multikolinearitas

\begin{tabular}{|l|c|c|}
\hline \multirow{2}{*}{\multicolumn{1}{|c|}{ Model }} & \multicolumn{2}{|c|}{$\begin{array}{c}\text { Collinearity } \\
\text { Statistics }\end{array}$} \\
\cline { 2 - 3 } & Tolerance & VIF \\
\hline $\begin{array}{l}\text { Keterlibatan } \\
\text { Kerja }\end{array}$ & .944 & 1.059 \\
\hline $\begin{array}{l}\text { Lingkungan } \\
\text { Kerja }\end{array}$ & .975 & 1.025 \\
\hline Budaya Kerja & .967 & 1.034 \\
\hline
\end{tabular}

\section{Pengujian Heteroskedastisitas}

Guna mengetahui adanya problem heteroskedastisitas sebaiknya menggunakan istilah uji gletser dapat dilihat pada Tabel 7 berikut :
Tabel 7

Uji Heteroskedastisitas

\begin{tabular}{|ll|c|c|}
\hline & & & \\
Model & & $\mathrm{t}$ & Sig. \\
\hline 1 & (Constant) & 1.184 & .242 \\
& & & \\
& Keterlibatan Kerja & .603 & .550 \\
& Lingkungan Kerja & -1.808 & .077 \\
& Budaya Kerja & .572 & .570 \\
\hline
\end{tabular}

a. Dependent Variable: Absut

\section{Hasil Analisis Regresi Linier Berganda}

Hasil analisis regresi linear berganda dapat dilihat pada Tabel 8 berikut ini :

\section{Tabel 8}

Hasil Persamaan Regresi Linier Berganda

\begin{tabular}{|l|r|r|r|}
\hline & \multicolumn{2}{|c|}{$\begin{array}{c}\text { Unstandardized } \\
\text { Coefficients }\end{array}$} & $\begin{array}{c}\text { Standardized } \\
\text { Coefficients }\end{array}$ \\
\cline { 2 - 4 } Model & \multicolumn{1}{|c|}{ B } & Std. Error & \multicolumn{1}{c|}{ Beta } \\
\hline $1 \quad$ (Constant) & 12.184 & 2.893 & \\
Keterlibatan Kerja & .270 & .125 & .289 \\
Lingkungan Kerja & -.345 & .135 & -.335 \\
Budaya Kerja & .293 & .162 & .238 \\
\hline
\end{tabular}

a. Dependent Variable: Kinerja Karyawan

Tabel 4.8 menunjukan bahwa model yang digunakan untuk menduga pengaruh tersebut adalah :

$$
Y=12,184+0,270 X_{1}-0,345 X_{2}+0,293 X_{3}
$$

\section{Pengujian Hipotesis}

\section{Hasil Uji Serempak (Uji F)}

Uji $F$ ini dilakukan untuk menguji secara serempak apakah keterlibatan kerja, lingkungan kerja dan budaya kerja berpengaruh positif dan signifikan terhadap kinerja karyawan, dapat dilihat pada Tabel 9 berikut : 
Hasil Uji Serempak (Uji F)

\begin{tabular}{|l|r|r|r|r|r|}
\hline \multicolumn{1}{|c|}{ Model } & $\begin{array}{r}\text { Sum of } \\
\text { Squares }\end{array}$ & Df & $\begin{array}{c}\text { Mean } \\
\text { Square }\end{array}$ & F & Sig. \\
\hline 1 Regression & 52.689 & 3 & 17.563 & 4.825 & $.005^{\mathrm{a}}$ \\
Residual & 163.801 & 45 & 3.640 & & \\
Total & 216.490 & 48 & & & \\
\hline
\end{tabular}

a. Predictors: (Constant), Budaya Kerja, Lingkungan Kerja, Keterlibatan Kerja

b. Dependent Variable: Kinerja Karyawan

Hasil Uji Parsial (Uji t)

Uji parsial (uji t) dilakukan untuk menguji secara parsial (individu) apakah keterlibatan kerja, lingkungan kerja dan budaya kerja berpengaruh positif dan signifikan terhadap kinerja karyawan, dapat dilihat pada Tabel 10 berikut :

Tabel 10

Hasil Uji Parsial (Uji t)

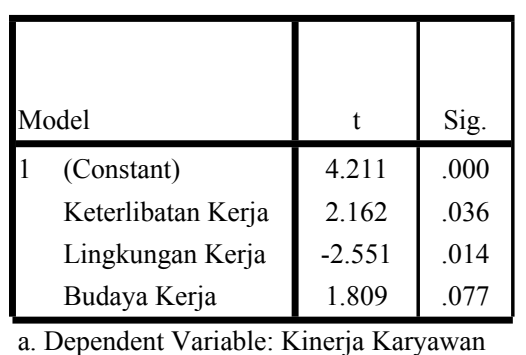

Analisis Koefisien Determinasi $\left(\mathbf{R}^{\mathbf{2}}\right)$

Analisis koefisein determinan digunakan untuk melihat seberapa besar pengaruh variabel bebas terhadap variabel terikat. Hasil pengujian koefisien determinasi dapat dilihat dari Tabel 11 sebagai berikut :

Tabel 11

Hasil Koefisien Determinasi $\left(\mathbf{R}^{\mathbf{2}}\right)$

\begin{tabular}{|c|c|c|c|c|}
\hline Model & $\mathrm{R}$ & R Square & $\begin{array}{l}\text { Adjusted } \\
\text { R Square }\end{array}$ & $\begin{array}{l}\text { Std. Error } \\
\text { of the } \\
\text { Estimate }\end{array}$ \\
\hline 1 & $.493^{\mathrm{a}}$ & .243 & .193 & 1.90788 \\
\hline
\end{tabular}

a.Predictors: (Constant), Budaya Kerja, Lingkungan Kerja, Keterlibatan Kerja

b.Dependent Variable: KinerjaKaryawan

\section{Pembahasan}

1) Secara Serempak Keterlibatan Kerja, Lingkungan Kerja Dan Budaya Kerja Berpengaruh Positif dan Signifikan Terhadap Kinerja Karyawan.

Secara serempak variabel keterlibatan kerja, lingkungan kerja dan budaya kerja berpengaruh positif dan signifikan terhadap kinerja karyawan. Keterlibatan kerja sebagai internalisasi nilai-nilai tentang kebaikan pekerjaan atau pentingnya pekerjaan bagi keberhargaan seseorang. Keterlibatan kerja sebagai tingkat sampai sejauh mana performansi kerja seseorang mempengaruhi harga dirinya dan tingkat sampai sejauh mana seseorang secara psikologis mengidentifikasikan diri terhadap pekerjaannya atau pentingnya pekerjaan dalam gambaran diri totalnya. Individu yang memiliki keterlibatan yang tinggi lebih mengidentifikasikan dirinya pada pekerjaannya dan menganggap pekerjaan sebagai hal yang sangat penting dalam kehidupannya. Setiap organisasi, pada umumnya baik yang berskala besar, menengah, maupun kecil, semuanya akan berinteraksi dengan lingkungan dimana organisasi atau perusahaan tersebut berada.

2) Secara Parsial Keterlibatan Kerja Berpengaruh Positif dan Signifikan Terhadap Kinerja Karyawan.

Secara parsial keterlibatan kerja berpengaruh baik positif dan signifikan terhadap kinerja karyawan. Pengambilan keputusan dalam organisasi dapat dipandang sebagai suatu rangkaian kesatuan dari kontrol manajemen total dan dominasi pekerja. Diantara rangkaian tersebut sejumlah tingkat keterlibatan yang berbeda dapat dibedakan. Perbedaan umum yang paling menonjol adalah komunikasi ke bawah dari manajemen, sistem komunikasi dua 
arah atau bilateral, pengaturan konsultasi dimana para karyawan diberi kesempatan untuk memperoleh hak yang sesungguhnya di dalam pengambilan keputusan, sistem pengendalian yang didelegasikan, dan berbagai macam pengambilan keputusan bersama.

3) Secara Parsial Variabel Lingkungan

Kerja Tidak Berpengaruh Positif Dan Signifikan Terhadap Kinerja

Karyawan.

Secara parsial variabel lingkungan kerja tidak berpengaruh positif dan signifikan terhadap kinerja karyawan. Pengaruh lingkungan kerja merupakan hal yang tidak boleh dikesampingkan oleh perusahaan karena akan berdampak pada kinerja karyawan yang berpengaruh terhadap perusahaan. Menurut Soetjipto (2004:87) pengaruh lingkungan kerja adalah segala sesuatu hal atau unsur-unsur yang dapat mempengaruhi secara langsung maupun tidak langsung terhadap organisasi atau perusahaan yang akan memberikan dampak baik ataupun buruk terhadap kinerja karyawan. Pengaruh atau perubahan eksternal dalam lingkungan kerja yaitu persaingan domestik dan internasional (kinerja karyawan dan pemberdayaan), karakteristik demografi (gender, pendapatan, minoritas, mayoritas, dan diversitas angkatan kerja), karakteristik angkatan kerja (tingkat pendidikan dan nilai budaya kerja).

\section{4) Secara Parsial Budaya Kerja}

Berpengaruh Positif Dan Tidak

Signifikan Terhadap Kinerja

Karyawan.

Secara parsial budaya kerja berpengaruh positif dan tidak signifikan terhadap kinerja karyawan. Budaya Kerja merupakan suatu falsafah yang didasari oleh pandangan hidup sebagai nilai-nilai yang menjadi sifat, kebiasaan dan kekuatan pendorong, membudaya dalam kehidupan suatu kelompok masyarakat atau organisasi, kemudian tercermin dari sikap menjadi perilaku, kepercayaan, cita-cita, pendapat dan tindakan yang terwujud sebagai "kerja" atau "bekerja" Budaya Kerja organisasi adalah manajemen yang meliputi pengembangan, perencanaan, produksi dan pelayanan suatu produk yang berkualitas dalam arti optimal, ekonomi dan memuaskan.

\section{KESIMPULAN DAN SARAN \\ Kesimpulan}

Adapun kesimpulan pada penelitian ini sebagai berikut :

1. Secara serempak variabel keterlibatan kerja, lingkungan kerja dan budaya kerja berpengaruh positif dan signifikan terhadap kinerja karyawan.

2. Secara parsial variabel keterlibatan kerja paling dominan berpengaruh positif dan signifikan terhadap kinerja karyawan.

3. Secara parsial variabel lingkungan kerja tidak berpengaruh positif dan signifikan terhadap kinerja karyawan.

4. Secara parsial budaya kerja berpengaruh positif dan tidak signifikan terhadap kinerja karyawan.

\section{DAFTAR PUSTAKA}

Akinbobola, O.I. 2011.Conflict in Human Capital Relationships: the Impact of Job Satisfaction on Job Involvement in a Workplace. International Journal of SocialScience and Humanity. Vol. 1 No. 2, Juli 2011. 
Arianto, Dwi Agung Nugroho. 2013. Pengaruh Kedisiplinan, Lingkungan Kerja, Dan Budaya Kerja terhadap Kinerja tenaga Pengajar. Jurnal Economia. Vol.9, No.2.

Basri, A. F. M., dan Rivai, V. 2005. Perfomance Appraisal.Jakarta:PT Raja Grafindo Persada.

Cilliana, dan Mansoer, D.W. 2008. Pengaruh Kepuasan Kerja, Keterlibatan Kerja, Stres Kerja, Dan Komitmen Organisasi Terhadap Kesiapan Untuk Berubah Pada Karyawan PT Bank Y. Jurnal Psikologi, 14 (2), 151-164.

Daryatmi. 2005. Pengaruh Motivasi, Pengawasan Dan Budaya Kerja Terhadap Produktivitas Kerja Karyawan Perusahaan Daerah Bank Perkreditan Rakyat Badan Kredit Desa Kabupaten Karanganyar. http : //eprints.ums.ac.id/125/1/Daryat mi.pdf

Ferdinand. Augusty. 2006. Metode Penelitian Manajemen.

Semarang: Badan Penerbit Universitas Diponegoro

Ghozali, Imam. 2013. Analisis Multivariate dengan Program SPSS. Semarang: Badan Penerbit Universitas Diponegoro.

Kartiningsih. 2007. Analisis Pengaruh Budaya Organisasi dan Keterlibatan Kerja Terhadap Komitmen Organisasi dalam Meningkatkan Kinerja Karyawan (PT. Bank Tabungan Negara (Persero) Caban Semarang). Journal Diponegoro
University Institutional Repository (UNDIP).

Logahan dan Aesaria. 2014. Budaya Organisasi Dan Keterlibatan Kerja Terhadap Komitmen Organisasi Berdampak Pada Kinerja Karyawan Pada BTN Ciputat. Binus Business Review Vol. 5 No. 2 November 2014: 551-563.1

Mathis, Robert dan Jackson, H. John., 2011. Human Resource Management (edisi 10). Jakarta : Salemba Empat.

Nitisemito, Alek S. 2006. Manajemen Personalia. Edisi kedua. Ghalia Indonesia.

Oktaviani, Hamusa. 2014. Pengaruh Lingkungan Kerja Dan Budaya Organisasi Terhadap Kinerja Karyawan Pada Koperasi Sumber Rejeki Rembang Jawa Tengah. Skripsi Fakultas Ekonomika Dan Bisnis Universitas Diponegoro Semarang.

Safaria, Siti. 2013. Pengaruh Keterlibatan Kerja Terhadap Kinerja Pegawai Pada PT Seascape Surveys Indonesia. E-Jurnal Manajemen dan Bisnis, Vol 1, No.1.

Sedarmayanti. 2009. Sumber Daya Manusia dan Produktivitas Kerja. Bandung: CV. Mandar Maju.

Sekaran, Uma 2006. Metodologi Penelitian Untuk Bisnis. Jakarta: Salemba Empat. 